\title{
An Evaluative Study of Criminalistics: A Case of South African Counterfeiting and Knock-Off Menacei
}

\author{
Godfrey Thenga \\ University of South Africa, Johannesburg, SOUTH AFRICA \\ College of Law, Department of Police Practice
}

Received: 16 April 2020 • Accepted: 26 May 2020 • Published Online: 6 November 2021

\begin{abstract}
Counterfeit goods are a health hazard to human life, environment and business. More so as the goods destroy the viability of legitimate businesses across the world. Counterfeit goods are characterized as a threat to the financial viability of legitimate businesses and has a dire impact on the tax revenue of countries, necessitating its effective and efficient policing for the financial wellbeing of countries. If not well managed, counterfeit goods could lead to unemployment, disinvestment and capital flight in countries. The available evidence reveals that even though counterfeit goods has dire consequences for the economic wellbeing of countries, its penalties in most African countries are less severe in comparison to penalties for other crimes. The sight of counterfeit goods in many places, such as on busy street corners and transportation terminals in the Southern parts of Africa, attests to its prevalence in the continent. Especially in South Africa as the country has become a transit point for contrabands. Post 1994, South Africa opened its borders to the world of branded and protected goods and this enabled rogue people to trade in counterfeit goods. Effective policing is hindered by the use of sophisticated skills and expertise that leads to counterfeit goods resembling genuine goods. Moreover, in South Africa, the problem persists despite the promulgation of the Counterfeit Goods Act 37 of 1997, thus questioning the effectiveness of the policing strategies in use to quell the problem.
\end{abstract}

Keywords: consumer fraud, policing of counterfeit goods, dealing with counterfeit goods, corruption, money laundering.

\section{Introduction}

On the African continent, countries are awash with counterfeit and knock-off goods. South Africa as a thriving economy is not exempted from the counterfeit menace (South African Institute of Intellectual Property Law, 2015). The streets and shops in the country's biggest cities are inundated with traders who, daily, sell counterfeit goods to knowing and unsuspecting consumers, despite the fact that trading in counterfeit goods is a property crime. Counterfeit dealing is a crime that, among others, infringes on intellectual property and it is consumer fraud, as some of the goods are smuggled into the country in violation of the laws. Some of the goods are registered to be sold only in specific markets and may not be suitable for the other markets into which they were smuggled. This crime hampers innovation and creativity in all nations (Spilsbury, 2009: 4). Protected goods, which are goods registered by the owner in respective countries, enjoy a dominant status conferred by the state to prevent exploitation by unscrupulous people who would want to steal creative and innovative products of others (Staake \& Fleisch, 2008: 33). By law, only legitimate manufacturers should produce and distribute goods, without having to

(C) Authors. Terms and conditions of Creative Commons Attribution 4.0 International (CC BY 4.0) apply. Correspondence: Godfrey Thenga (PhD, Senior lecturer), University of South Africa, College of Law, Department of Police Practice, Johannesburg, SOUTH AFRICA. E-mail: tshabg@unisa.ac.za. 
compete with illegitimate dealers in the market. It is the duty of law enforcement officials in every country to enforce the law and prevent crime. In South Africa, the South African Police Service (SAPS) is responsible for enforcing the law and policing crime that occurs within the borders of the country.

Counterfeit goods manufacturers are located in countries around the world. Often, manufacturers of counterfeit goods and dealers form part of organized criminal groupings and, to make matters worse, they make use of unregulated and hazardous materials in producing such goods. Counterfeit goods are often an imitation of genuine goods that are smuggled into the country in dubious ways by criminals without the permission of the owners of original goods (Beauchamp, 1998: 278).

Consumer fraud involves the use of falsehood to misrepresent facts to deceive consumers. Production of counterfeit goods that resemble genuine goods, and the selling of such goods purported to be what they are not, with the ultimate goal of making an exorbitant profit, amounts to consumer fraud (Treadwell, 2011: 176). Criminals who counterfeit goods that are owned by other people, earn an unlawful income because they had not spent money on conducting research, developing the goods and procuring quality materials. A study conducted by BASCAP (2009: i) on the dangers and extent of counterfeit goods, revealed the grievous losses that counterfeit goods cause governments and the lawful owners of genuine goods to suffer. Counterfeit goods stall economic growth as taxes are not paid to the tax collector, the South African Revenue Services in the case of South Africa. Jobs are lost as criminals do not employ many people, nor do they have research and development teams working in their organizations as opposed to the genuine goods industry. Innovation suffers because counterfeit products discourage creativity and slow sector or industry expansions, which lead to mass job creation. Consumers across the world may suffer injuries. Finally, the legitimate owners of genuine goods become reluctant to invest in expansion drives and increase their presence in businesses.

Counterfeit goods have not been tested by authoritative and accredited institutions to determine if the materials used in producing them may be harmful to people and environment. Even the consumers of counterfeit goods find it difficult to differentiate whether the goods are genuine or counterfeit goods (Bian \& Veloutsou, 2007: 212). Consequently, criminals leverage on this lag and continue to sell these goods on the street and in shops to consumers in many countries, including South Africa.

Despite a considerable body of literature on the dangers that counterfeit products pose to people both nationally and internationally, no research study has yet been conducted on the policing of counterfeit goods in South Africa and on the African continent. It is against this background that the article will highlight the extent of the problem in South Africa from a policing perspective and the issues which complicate the policing of it. Furthermore, this study will suggest guidelines for the policing of such goods in order to suffocate the trade.

\section{Definition of concepts}

Counterfeit is the unlawful and intentional misrepresentation of goods that effectually cause actual or potential prejudice to another (Treadwell, 2011: 176). This is the imitation of genuine goods by the counterfeiter without permission of the genuine goods holder and at times passing them off as genuine.

Knock-off is a copy or imitation of the original goods that are presented to consumers as if they are original, by hiding their true identity.

Trademark is a distinctive sign and/or mark that identifies the goods that are owned by an enterprise (Ward, 2011: 49). It is a symbol or device used to identify and distinguish goods manufactured, owned and registered by different businesses. 


\section{Policing}

South Africa as a global village is no exception as counterfeited goods are spotted in many places such as residential areas, busy streets and transportation terminals in cities. This crime continues unabated despite the Counterfeit Goods Act 37 of 1997 as the main legislation that criminalizes counterfeiting. This study focuses on the policing of counterfeiting in South Africa and analyses the capabilities and abilities of the SAPS to police inland counterfeiting. The Constitution of the Republic of South Africa 108 of 1996 and the SAPS Act 68 of 1995 mandate the SAPS to police crime (South Africa, 1996a). The police are required to consciously strive to create an atmosphere of safety and security and protection of property in the country (Large, 2009: 4). In addition, Wells (2016: 274) asserts that counterfeiting often takes place in communities and will need community involvement in policing. Moreover, Customs and Excise and the Department of Trade and Industry also enforce the Counterfeit Goods Act 37 of 1997 amid the spread of the problem.

\section{The counterfeiting and knock-off problem in South Africa}

Counterfeiting infringes property rights. In South Africa, the 1996 Constitution protects property rights. Section 25 of the Constitution makes it a criminal offence to violate individual property rights. Copyrights are unregistered rights that allow copyright owners to prevent the unauthorized reproduction of their goods, whereas counterfeit often takes place on registered goods that are identified by trademarks. The fact that the owners of genuine goods do not have to register as legitimate owners does not justify the reproduction of their products without their permission. Their ownership is automatically protected by the state. Counterfeiting is an enormous problem globally. Business Software Alliance claims that $98 \%$ of the software used in China, including that used by the Chinese government, are illegal copies (Beauchamp, 1998: 278). China is regarded as the capital of counterfeit and copyright crimes. The cost-benefit analysis gives a better explanation of the economic benefits of counterfeiting (Pires, Schneider \& Herrera, 2016: 5). Criminals engage in criminal activities that are intended to reward them financially and this principle seems to hold in counterfeiting. SAFACT (2009:2) alleges that criminals use airports to bring counterfeit goods to South Africa.

In the modern epoch, counterfeiting manifests in various ways, with similar characteristics of deceiving and defrauding people. Its key motive is financial gain. Counterfeiting is a financial crime that is growing significantly the world over (Basu \& Lee, 2015: 39). It can be said wherever people are located, counterfeiters and or counterfeit goods are found. The involvement of underworld-organized criminals in counterfeiting is an indication of the lucrativeness of the business (Rojek, 2016: 1). A study conducted by Heinonen and Wilson (2012: 273) reported that counterfeiting's yearly turnover in the world is comparable with proceeds of illegal drug trafficking business.

Counterfeiting is almost the same as forgery in that something is copied to defraud buyers by passing it off as the original or genuine product. It is legally singled out from other acts of forgery and is treated as a separate crime. In general, counterfeiting impacts negatively on the relationship that people have with the authentic branded products (De Chermatony, Mcdonald \& Wallace, 2011: 397). Owing to the skill and sophistication with which counterfeit products are produced, most of them end up looking like genuine products, therefore making it difficult, if not impossible, for people to distinguish between them. Consequently, counterfeiting has a severe negative impact on international trade and the global economy (Heike, 2010: 159). Its enormity on a global scale negatively affects the growth and operation of most start-ups and established businesses (Phau \& Teah, 2009: 15). 
Counterfeiting contributes to brand equity damage which, in turn, causes businesses to lose plenty of money due to lost sales, lower profits, fewer royalties, and loss of trust in the brand. Businesses end up reducing the financial loss by cutting jobs and reducing investment, in turn leading to lower economic growth. The personal and family trauma for people who lose employment is disastrous as they fail to service mortgages and other personal debts that they might have, while others end up having to relocate to cheaper accommodation or become homeless. UNICRI (2011: 47) states that even for those fortunate enough to find other employment, the possibility of finding employment that pays less than the previous employment is huge. A study by Bikoff, Heasley, Sherman and Stipelman (2015: 246) reveal that counterfeit drugs and medicine cause more than 100,000 deaths on the African continent on an annual basis.

Consumers receive poorer quality products that are unregulated and unsafe for their health. Once their health deteriorates, this is likely to cause financial burden on the government. Most of the counterfeit goods are hazardous and they need to be disposed of properly; however, this causes the government a lot of money and renders the country a dumping ground for hazardous goods. Many consumable goods are counterfeited, such as baby formulas, automobile car parts, electrical equipment, surgical and hospital equipment such as Covid-19 test kits, masks, sanitizers among others. According to Joossens, Chaloupka, Merriman and Yurekli (2000: 394), businesses also need to guard against being wrongly litigated based on harmful products that consumers mistake to be the genuine brands that are sold by that business. They spend more money in protecting their goods through private policing and protective measures on packaging in order to differentiate them from fake goods, mostly with no success. This expenditure is often passed to consumers who ultimately pay more for the product.

However, Estacio (2013: 397) indicates that working conditions in the counterfeit industry are poor. Most companies offer low remuneration and workers are often exposed to health and safety risks compared with employment created by legitimate businesses that offer employment benefits and job security. It is important to note that counterfeiting also affects the fiscal wellbeing of governments in various ways. The fiscal cost of counterfeiting ranges from its policing to tax avoidance (OECD, 2008: 134). According to Cohen (2000: 272), there might even be a need for the government to increase the policing expenditure budget by employing additional police officers who will be dedicated to deal with this crime.

\section{The extent and magnitude of counterfeiting globally}

Counterfeiting figures stand at around $6 \%$ to $10 \%$ of all trade globally, and the industry is projected to earn more than $\$ 600$ billion annually (Lewis, 2009: 47). The above figure was for 2008 and the numbers have since increased substantially with global trade uptake. In 2009, the United Nations (UN) reported that counterfeit trade constituted $7 \%$ of the world trade, an equivalent of 600 billion US dollars a year globally. This report further indicated that industries such as the computer software industry, and online streaming are lucrative markets for criminal syndicates that also produce drugs and illegal substances (Basu \& Lee, 2015: 39).

According to the OECD (1998: 30), 67\% of the world's counterfeited goods originate from China. It causes South African businesses an annual loss of billions of dollars in imported goods. These include a loss in sales, goodwill and royalties, among others (South African Institute of Intellectual Property Law, 2013: 16). Most criminals run the counterfeit business supply chain in a way similar to that of a legitimate business, with undesirable consequences. The fact that some of the legitimate business owners mingle their genuine products with counterfeit goods, is unfair to legitimate producers and owners of goods (Joyce, 2011: 76).

The 2008 data of the value of illicit trade shows that the total global economic value of counterfeited products was 650 billion US dollars annually. South Africa, as a developing nation, 
is also included in the figures. According to the ICC (2010), the impact of counterfeited goods would exceed 1.77 trillion US dollars, with a possibility of more than 2.5 million people being placed out of work and not being able to earn a livelihood.

Figure 1 below displays the growth trajectory of counterfeit trade worldwide and the sharp escalation of this crime from 1980 to 2010.

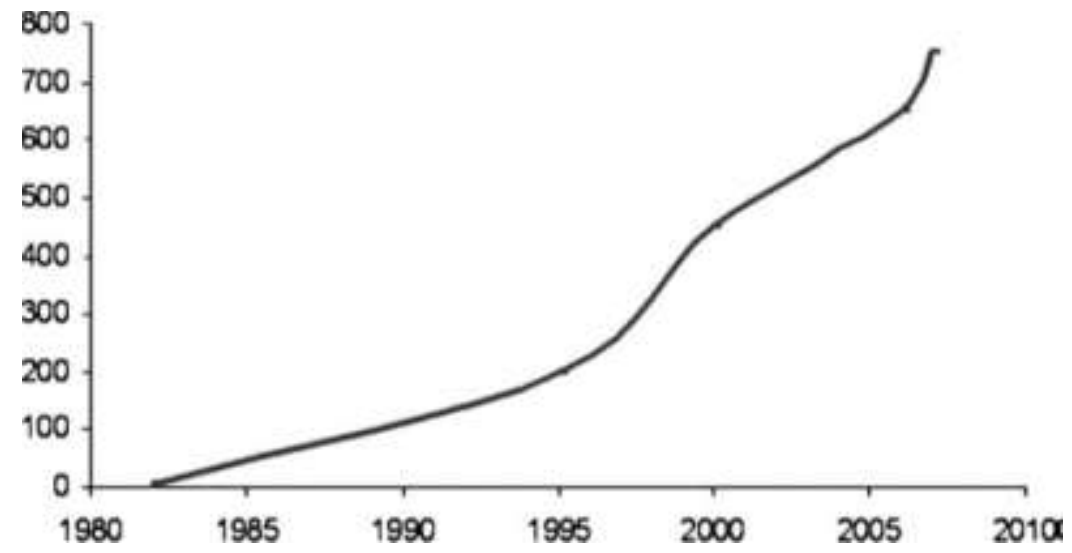

Figure 1: Growth in the counterfeit goods market

Source: INTERPOL.

The above figure 1 by INTERPOL (2014: 7) shows the rate at which counterfeit trade has increased in various nations across the world. In 2010, the proceeds from counterfeit trade was 800 million US dollars, and this figure has since increased astronomically. No country in the world is unaffected by the problem; only the degree in which they experience it varies.

6. Theories of crime to explain the proliferation of counterfeit trade

The growth of counterfeit trade is attributed to the growing population of young people (Spoor \& Fisher, 2013: 3). It is well known that the youth admire popular brands and would usually purchase branded goods or goods that are associated with prestige. Klijn, Eshuis and Braun (2012: 499) aver that a brand distinguishes a certain product from others. It can be any name, term, symbol or design that is identified with the good, and its intention is to make the good unique.

The police have the responsibility to protect legitimate businesses' intellectual property against criminals, since trespassing on intellectual property is a property crime. In South Africa, property crimes are prohibited by the Constitution.

The following theories will be used to explain counterfeiting.

\subsection{Strain theory}

The strain theory postulates that for a crime to occur, there needs to be conflict between a person's goals and the way to achieve them. The theory posits that people share similar goals and values, and wish to live a better life. Unfortunately, the ability to achieve these personal goals is stratified by socioeconomic class. While the affluent may live the good life, the poor are barred from achieving their goals. Because they cannot have what they want, they begin to feel frustrated and angry, a condition which is referred to as strain (Agnew, 1992: 47). 


\subsection{Rational choice theory}

The rational choice theory has its roots in the classical school of criminology developed by the Italian social thinker, Cesare Beccaria. Beccaria and other utilitarian philosophers suggest that people choose their behavior, including criminal behavior. Their choices are designed to bring them pleasure and reduce pain. Criminal choices can be controlled by fear of punishment and the more severe the punishment, the greater its ability to control criminal behavior (BASCAP, 2011: 17). This agrees with the economic theory of crime that professes that individuals respond rationally to the costs and benefits of criminal opportunities. In relation to counterfeiting, for instance, the point of departure in economic analysis is the existence of a market. Individuals who embark in counterfeiting for profit and escape detection and conviction, make up the supply side of this market (Forst, 2009: 29).

\subsection{Routine activity theory}

The routine activity theory asserts that crime depends on the opportunities available at a specific place (Cohen \& Felson, 1979: 588). The logic of this theory is that crime does not need hardened offenders, super predators or convicted criminals, but just an opportunity. The routine activity theory underlies situational crime prevention and identifies the minimal elements that must converge in space and time in order to make crime possible (Reynald, 2011: 4). These elements are as follows (Siegel, 2010: 78):

- the availability of suitable targets,

- the absence of capable guardians such as police in the case of counterfeiting,

- the presence of motivated offenders.

The high returns on the sale of counterfeit goods, lenient punishment if caught by the police, and poor law enforcement are some of the factors that encourage this criminal enterprise. Most people who trade in counterfeited goods do not serve prison sentences, but are often only fined. The light sentences handed down for this crime by presiding officers have negative consequences for the country, families and legitimate businesses (Rich, 2016: 118).

\subsection{Situational crime theory}

This theory postulates that crime can be prevented or displaced through protective measures. Situational crime prevention regards crime as a rational choice made by the offender after several opportunities for the crime in a given situation have been evaluated (Clarke, 1997: 2). In other words, the offender conducts a risk assessment. The greater the opportunity for offending, the greater the likelihood that the motivated offender will commit the crime. That is why AIC (2003: 1) postulates that target hardening is one of the principles of preventing crime. Target hardening in counterfeiting can be achieved through visible policing, properly trained investigators who are deployed to enforce the Counterfeit Goods Act, maintaining proper controls at the ports of entry, searching people, goods and motor vehicles properly, confiscating counterfeited goods, and arresting the perpetrators.

\section{International legislative framework regulating counterfeiting of goods}

Intellectual property crime is a crime of the mind. It could be divided into industrial property such as patents, trademarks, industrial designs, geographical indications and copyright that covers literature, films, music, art, architectural designs as well as recordings (WIPO, 2014: 2). Sonmez (2014: 758) asserts that counterfeiting is an attractive business for free riders. Kerns (2016: 573) equates it with the capturing of another person's ideas by developing and imitating 
products without incurring a significant investment, thereby eroding the competitive edge of the original product owner.

Articles 6 and 7 of the United Nation's Convention against Transnational Organised Crimes, also referred to as the Palermo Convention, make money laundering a criminal offence deserving of sanction (United Nations, 2004). Another convention that makes money laundering punishable is the United Nations Convention against Illicit Traffic in Narcotic Drugs and Psychotropic Substances, which was adopted in 1998. This Convention criminalizes illicit trafficking, which could also be interpreted as the trafficking of money and drugs, and encourages governments to confiscate blood money and the proceeds of crime.

\subsection{Organized crime}

Organized crime thrives when money is involved. Counterfeiting is the most common commercial crime that organized crime engage in to finance their activities (Beare, 2012: 77). South Africa is well positioned as a transit point with 72 ports of entry surrounding it. International criminals have been operational in the country even before the 1994 democratic dispensation. These criminals pose a serious security threat to the country (Govender, 2012: 1). Members of organized crime are a specialized subset of a criminal enterprise who maintain their position using violence, blackmail and money laundering activities. Businesses that are run by organized criminals are well resourced and sustainable as they have various funding streams (Spink, Meyer, Park \& Heinonem, 2013: 60). The danger of organized criminals operating businesses is that they mingle genuine goods with counterfeit goods and have small armies that are responsible for squashing opposition. Legitimate businesses that are profitable are extorted and owners are threatened to pay bribes as a protection fee. Criminal bosses use sophisticated means, have significant financial resources, and are domiciled across the globe (Spink et al., 2013: 6o). Many of them buy farms and smallholdings and use them as hideout and manufacturing sites, whereas some own properties in various countries.

Organized criminals are able to rope in countries' government officials to overcome administrative hurdles, avoid paying taxes, access privileged government information, and are tipped off by the authorities if they were reported for the violation of laws (Balsamo, 2006: 373377). Organized crime is known to be indulging in capital flight activities. This behavior by government officials is tantamount to sharing confidential and protected information with criminals (Payne, 2013: 66). This conduct is unethical as privileged information is given out to the public in exchange of payment (Adejumo, 2010: 2). In terms of section 1 of the Prevention of Organised Crime Act, 121 of 1998, police officials who have legitimate access to and control of sensitive information yield to corruption if they exchange it with criminals. Consequently, governments are often unable to fight organized crime.

\subsection{Money laundering}

According to Le Khac, Markos, O’Neill, Brabazon and Kechadi (2011: 504), money laundering is the third largest business in the world. Its turnover is estimated at between 500 billion and 1 trillion US dollars annually. Money from criminal activities is laundered to disguise its origin and elevate it to a legitimate status. Money laundering makes crime a worthwhile endeavor for criminals (Mackrell, 1996: 47, South Africa, 1996b: 13). According to Choo and Smith (2008: 45) and the Financial Action Task Team Guidance (2013a: 28), these criminals:

- use agents and mules to open bank accounts for them where transactions will be made to launder the money and/or; 
- use their intermediaries, family and close associates to launder the dirty money on their behalf and they pay them a service fee or bribe.

Counterfeiting is a consumer fraud and is, according to the police in South Africa, perpetrated mostly by organized criminal gangs with links with the Chinese Triad from Hong Kong and Taiwan, such as the $14 \mathrm{~K}$ and the Wo Shing Wo (Gastrow, 1999: 62). The above assertion confirms that organized crime existed even before the democratic dispensation in South Africa. Organized criminals are aware that they are wanted by the police and attempt to evade justice through devious means, such as hiding the proceeds of crime and source of money when transacting. Figure 2 below displays the process of money laundering around the world.

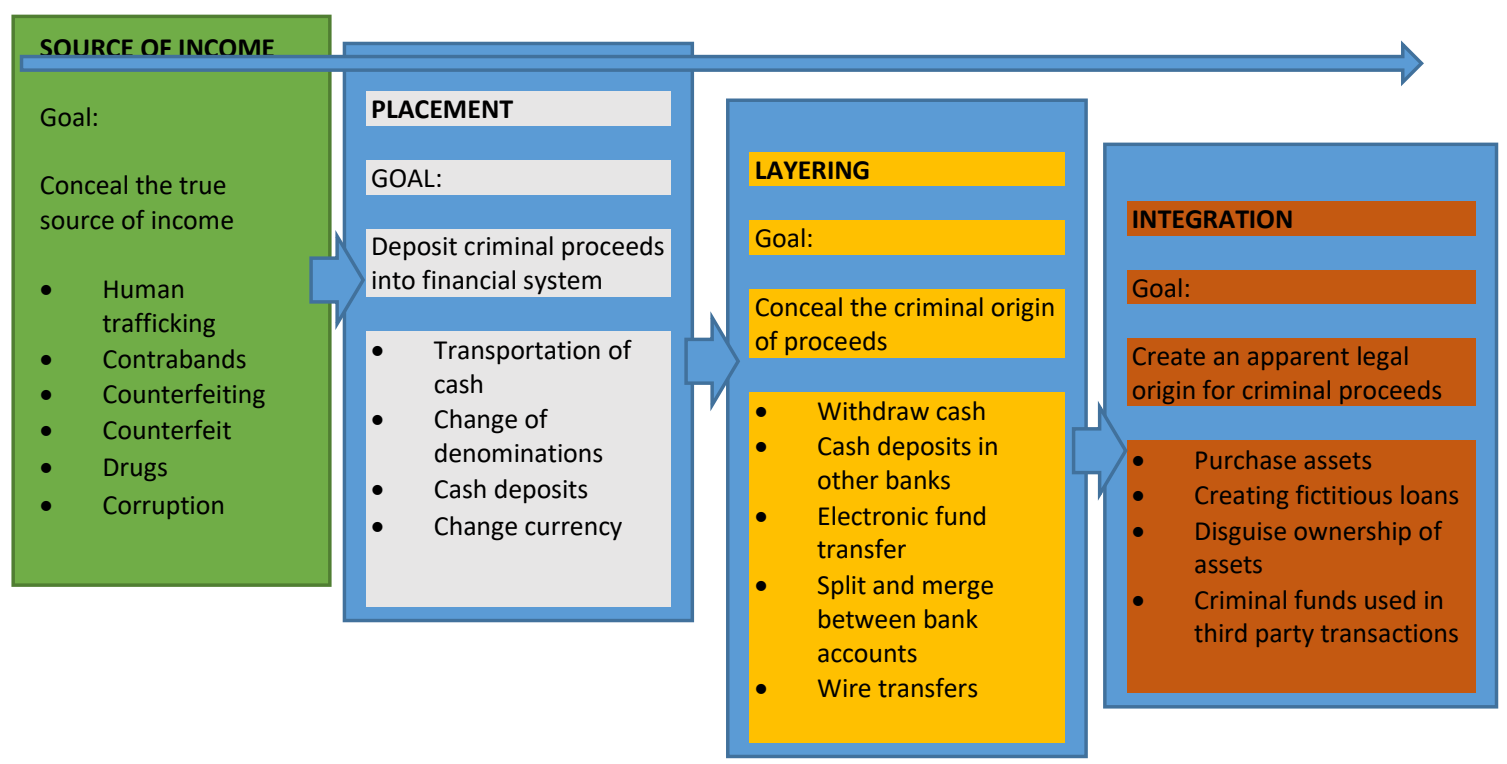

Source: Choo and Smith (2008: 46).

Figure 2: Process of money laundering

Figure 2 above explains the money laundering flow as set out by the Financial Action Task Force (FATF). South Africa is a member of the FATF, an organization which sets international standards to combat money laundering and terrorism around the world (Tuba, 2012: 103). All member countries are required to conclude international agreements to combat transnational crimes such as terrorism and organized crime.

\section{Research methodology}

This article is an evaluating study of criminalistics on counterfeiting in South Africa as a whole. A qualitative approach and empirical design were followed in this study. Miles, Huberman and Saldana (2014: 11) describe it as a study that covers an array of interpretive techniques and seeks to describe, decode and translate information to find the meaning of a naturally occurring phenomenon in the social world. The design was appropriate for this study as there was little information in literature that could achieve the objective of this study. The following three research methods were used to collect data:

Purposive sampling - Purposive sampling was used to identify and interview Specialised Commercial Crime Unit investigators who investigate counterfeit crime. In total, 20 investigators were interviewed. These investigators were selected for interviews based on their intimate knowledge and experience in the policing of 
counterfeit goods. Purposive sampling was also used to identify and interview 14 prosecutors who prosecute counterfeit crimes.

Snowball sampling - Crime Prevention Unit members working at police stations next to Specialised Commercial Crime Units who police counterfeit goods by arresting vendors trading in counterfeit goods and confiscating suspicious counterfeited goods, were selected through snowball sampling, and interviewed. The number interviewed is 332 .

Brand owners were identified though snowball sampling, and totaled ten. Nine members of the Department of Trade and Industry who deal with counterfeit goods were interviewed. Attorneys who, in most cases, legally represent accused in counterfeit cases and others who are employed by brand owners or represent them in court cases, were interviewed and tallied 21.

Observation - The researcher used this design to obtain credible data from respondents and the observation of raids. Permission was granted by the responsible employers that observation be conducted without those being observed knowing that they were being observed. This would ensure that they did not modify their practice due to being observed, as this could have led to inaccurate findings. A video recorder was used in seven raids that were conducted in various places to record the conduct of police and suspects during searches and the seizure of counterfeit goods. Recordings were made in such a way that people were unaware that they were being observed.

The study was conducted for the period 1 April 1998 to 31 March 2018. This period is significant as a result of its association with the start of the democratic dispensation in South Africa. It is characterized by increased trade with the international community and increased migrant intake, as the country had opened its doors to the world. Secondly, this is also the period in which the Counterfeit Goods Act 37 of 1997 was implemented in South Africa.

\subsection{Data analysis}

The data collected from interviews and the observation data were transcribed to facilitate the process. It was analyzed methodically according to the thematic method by classification into themes, subthemes and categories. To this effect, Tesch's eight-step data analysis method, as discussed in Creswell (2014: 198), was used. It involved getting a sense of the whole; picking one of the transcribed interviews and reading it carefully; making a list of topics and clustering them; coding and classifying information; making a final decision and alphabetizing the codes; assembling same categories; doing a preliminary analysis; and, finally, recording the data.

\subsection{Ethical considerations}

An ethical clearance was obtained from the College of Law at the University of South Africa before the commencement of this study. In this study, the researcher ensured confidentiality by not disclosing the personal details of the participants. The researcher obtained informed consent from all participants in this study. The participants consented to be interviewed and were not coerced to partake in the study; hence participation was voluntary. All participants were informed that they were permitted to withdraw from the interviews. Participants were not allowed to discuss their individual responses among themselves. The information they provided was kept in a safe place. Participants were not remunerated for participating in the interviews. Video recordings of the raids were made with the consent of the SAPS management. 


\section{Findings}

The literature, reinforced by most participants from the Specialised Commercial Crime Units, Crime Prevention Units, prosecutors, and the Department of Trade and Industry officials, shows that counterfeit goods generate a huge revenue for perpetrators. That is why there is constant innovation and increasing sophistication to produce and distribute these goods. According to several participants, some of the counterfeit goods are manufactured in South Africa and transported to and from neighboring countries and cities with private jets, which law enforcement would not suspect. Other goods are brought from various countries in different batches without identifiable marks, and once they are in the country, marks are affixed to them and they are sold as genuine products. Members of the Specialised Commercial Crime Units and some members of the Department of Trade and Industry also mentioned that criminals bring plain fabric, labels and manufacturing machinery into the country in separate consignments. Once all these consignments are in the country, they assemble these machines and start producing counterfeit goods. Most counterfeit goods are made of hazardous products that are expensive for a country to dispose of.

Literature reveals that effective policing of counterfeit goods requires a collective approach between the police and the private investigators hired by brand owners as well as the legal representatives and the experts who test disputed counterfeit goods and who are employed by the brand owners. Since expert testers and private investigators working for brand owners are located in big and economically thriving cities such as Johannesburg, Mbombela, Durban and Cape Town, they are not readily available in most areas to assist in the fight against counterfeit goods. Even though brand owners explain that such a location is based on sound financial considerations for their business, it does hamper the effective and efficient policing of counterfeit goods.

\subsection{Policing of counterfeit in South Africa}

Many countries do not regard this crime as a top priority that needs concerted policing. Most of them, including South Africa, do not punish the buying of counterfeit goods for private use. This means that only the sellers are prosecuted. In many African countries it is common that criminals in possession of a few counterfeited goods for household use are not prosecuted.

A member of the Specialised Commercial Crime Unit vindicated this as follows: "It is not a crime to carry few counterfeit goods for household use as long as one is not selling to the public, and this makes policing difficult as people would use household use as a defense when they are arrested."

South Africa lacks a coordinated system to keep statistics of counterfeit across the three major government departments that are involved in policing counterfeit, which are the DTI, Customs and Excise and the police. Uncoordinated information and communications technology (ICT) among these departments impedes progress in the war against counterfeit goods. Against that, some dealers use sophisticated technology to communicate and transact with their fellow perpetrators. Proper use of integrated technology by these government departments is essential for the effective and efficient policing of this crime by law enforcement agencies.

\subsection{Shortage of manpower in the Specialised Commercial Crime Unit}

There is shortage of workers with critical skills in the Specialised Commercial Crime Unit owing to natural attrition and members leaving this unit in droves for appointments in the private sector. This affects the capacity of the Unit to deal with counterfeit crime. This was confirmed by the then Acting Head of the Directorate for Priority Crime Investigation, Major- 
General Yolisa Matakata, when she briefed the Portfolio Committee on Police on 16 February 2018.

One Specialised Commercial Crime Unit member said: "A large number of the skilled commercial crime investigators are absorbed by the private sector and leave the SAPS in droves.”

\subsection{Corruption within the police and other law enforcement agencies}

Members of the Specialised Commercial Crime Units and Crime Prevention Units indicated that corruption is another factor that impedes an effective fight against counterfeit goods, because some police officials demand bribes and renounce their responsibility of confiscating counterfeit goods and arresting the perpetrators. Members of the Specialised Commercial Crime Units stated that the effective policing of counterfeit goods is further hampered by the fact that the possession of a few counterfeit goods for household usage is not punishable in South Africa, thus limiting the ability of the police to arrest people found with a few such items in their possession. One of the police members confirmed this by revealing that: "Many communities in the country have lost trust and legitimacy with the law enforcement members because they are corrupt."

According to some members of the Crime Prevention Units, Specialised Commercial Crime Units, Department of Trade and Industry, attorneys for brand owners and prosecutors, most counterfeit goods sellers in South Africa are desperate economic migrants, who eventually become counterfeit goods vendors without renting a selling area. Instead, they do business in areas such as transportation terminal ranks, and open streets to make a living.

\subsection{The nature and extent of counterfeiting in the world and in South Africa}

Some legitimate-goods owners stated that the fight against counterfeiting is undermined by the lack of a collaborative effort among production houses, since legitimate producers operate in secrecy to protect their products against copying. This is exacerbated by the fact that the use of protective items on goods means higher costs for producers. A member of the Specialised Commercial Crime Unit confirmed this by stating that: "China is responsible for producing many of the counterfeited goods that are circulating in the world."

Most respondents stated that counterfeit goods are often produced in large quantities and sold at a lower price than that of genuine goods. This explains why consumers are eager to buy them. Counterfeit goods have a huge target market, namely the youth. Young people buy them at train stations, taxi ranks, bus terminals, shopping complexes, and flea markets across South Africa. Most of the sellers are foreign nationals and many of them are undocumented immigrants. Some of the more sophisticated sellers advertise and sell their goods online.

Almost all members of the Specialised Commercial Crime Unit, crime prevention units and the DTI mentioned that porous borders make it easy to bring counterfeit goods in the country. Bribery of corrupt law enforcement officials is another factor that enables counterfeit trade to thrive. Counterfeit goods that are taken from one country to another complicate the effective and efficient policing of this crime. Illicit goods are transported by air and sea. Counterfeiting is a relatively easy enterprise and the considerable returns that it generates makes this crime attractive for terrorists and organized criminals who facilitate money laundering.

Criminals import plain goods, labels and machines to the country in separate consignments. Here they assemble the machines and reproduce goods that mimic the original. These are sold not only in South Africa but also in neighboring countries. In contrast with police 
in countries such as the USA and Britain, the South African police do not make use of intelligence in their policing of counterfeiting, and sporadic raids are seldom launched on sellers and dealers.

Members from Specialised Commercial Crime Units, Crime Prevention Units, the Department of Trade and Industry, and brand owners stated that arrested counterfeiters are represented by legal representatives and, if convicted, they mostly do not go to prison because they are given the option of paying a fine. This was emphasized by one member of the Crime Prevention Unit who stated the following: "The presiding officers of various courts do not impose sentences that are proportionate to the crimes that were committed."

\subsection{Characteristics of counterfeiting}

Members of the Specialised Commercial Crime Units, prosecutors and attorneys of brand owners indicated the difficulty of identifying and arresting leaders of organized counterfeit crime because they live all over the world. This is augmented by the difficulty of producing sufficient evidence that directly links them to counterfeit goods that are found elsewhere so that they could be successfully convicted, because they make use of other people to sell their consignments in various countries. Since some counterfeit goods resemble the genuine product, it is difficult, if not impossible, to identify them at a glance. Dealers of counterfeited goods re-invest most of their profits in goods manufacturing equipment. This high-tech equipment makes spotting counterfeited goods almost impossible. Because confiscated products need to be tested, many legitimate producers based in other countries send their testers (equipment) to South Africa to conduct tests. They also mention the tedious process of extraditing those who are arrested for prosecution in South Africa, because not all countries have extradition treaties with South Africa. One Crime Prevention Unit member emphasized this by stating as follows: "Counterfeited goods can only be discerned scientifically as a human eyes will find it difficult to confirm counterfeit on the goods."

Some legitimate-goods owners outsource the production of their goods to external producers who, in most cases, produce it in excessive numbers to earn a higher income. This is unethical as the producers are not the owners of the goods.

\subsection{Organized crime involvement in the counterfeit trade}

Organized criminals are active in the counterfeit business as they consider it less risky. People who are arrested for this crime tend to be represented by reputable legal representatives and, if they are convicted, most of them prefer paying a fine to serving a jail term. A Crime Prevention Unit member corroborated this by stating as follows: "Even the presiding officers do not impose sentences that are proportional to crimes committed."

Countries such as Finland, New Zealand, Sweden, Norway, Italy, France, and the USA, have stronger laws against counterfeiting and impose harsher sentences on dealers and sellers (Levy-Carciente, 2016: 16). It is difficult to identify and arrest the leaders of organized crime as they reside in various countries in the world, and produce sufficient evidence to arrest and convict them. The challenge of finalizing extradition arrangements between countries is also an impeding factor because not all countries are willing to enter into such agreements. Moreover, the leaders of organized crime syndicates use other people to sell their consignments in various countries.

\subsection{The strategy used to police counterfeiting}

Neither the SAPS nor the DTI has a strategy for dealing with criminals involved in counterfeit trade. Even the Specialised Commercial Crime Unit does not have strategy to police 
counterfeiting. The SAPS, the DTI and the Specialised Commercial Crime Unit follow a generic strategy referred to as the National Crime Prevention Strategy to fight crime including counterfeiting. Not even an in-house policy exists on how counterfeit crime should be policed.

\section{Conclusion}

Counterfeiting is a crime characterized by deception and fraud and yields sufficient income for the criminals. It cannot be effectively policed by the SAPS alone. They need the cooperation and expertise of all concerned, considering the sophistication and skills that are used to produce counterfeit goods to resemble the genuine goods. The findings and the implementation of the recommendations of this article could contribute to the effective and efficient policing of counterfeit goods in South Africa, especially since current policing strategies used to deal with this crime are not producing the desired results. This is evidenced by the availability of counterfeit goods in most marketplaces across the country and the impunity with which counterfeit goods are sold on most street corners. Counterfeit goods trade has undesirable consequences for people, business and government. The involvement of organized crime groupings in the trade is responsible for the upsurge in the crime as well as money laundering. It is apparent that the policing of counterfeiting is an enormous task that cannot be successfully achieved or accomplished by the SAPS alone. The involvement of other law enforcement stakeholders, such as Customs and Excise and the DTI, is critical. The failure of proactive policing is evident from the presence of counterfeit goods in the markets, and requires reactive policing to arrest perpetrators and deter potential criminals. The successful prosecution of perpetrators serves as both proactive and reactive crime prevention activities that lead to deterrence.

Corruption in the SAPS frustrates the fight against counterfeit goods trade. Threats made to the police can be eradicated by adopting proactive approaches to policing. These must involve intelligence and surveillance in policing, and an active society that works in conjunction with the police and other stakeholders. Proper policing of this crime could discourage perpetrators from committing it.

This study could assist the SAPS in policing counterfeiting. Other law enforcement stakeholders such as Customs and Excise and the DTI could also benefit from it. Successful law enforcement needs a rigorous, dynamic effort by all role players in policing.

\section{Acknowledgements}

This research did not receive any specific grant from funding agencies in the public commercial, or not-for-profit sectors.

The author declares no competing interests.

\section{References}

Adejumo, A. O. (2010). Relationship between psycho-demographic factors and civil servants' attitudes to corruption in Osun State, Nigeria. Internet Journal of Criminology, 1, 2-3.

Agnew, R. (1992). Foundation for a general strain: Theory of crime and delinquency. Criminology, 3o(1), 47-88.

AIC (2003). Crime reduction matters. Canberra: Australian Government Printer. 
Balsamo, A. (2006). Organised crime today: The evolution of the Sicilian mafia. Journal of Money Laundering, 9(4), 373-378.

BASCAP (2011). Estimating the global economic and social impacts of counterfeiting and piracy. London: Frontier Economics.

BASCAP (2009). The impact of counterfeiting on government and consumers. London: Frontier Economics.

Basu, M. M., \& Lee, Y. (2015). Factors affecting intention to buy counterfeit products. Marketing Management Association. Springs 2015 Proceedings, 39-47.

Beare, M. E. (2012). Encyclopaedia of transnational crime and justice. Los Angeles: Sage.

Beauchamp, E. R. (1998). Dimensions of contemporary Japan: A collection of essays. New York: Garland.

Bian, X., \& Veloutsou, C. (2007). Consumers' attitudes regarding non-deceptive counterfeit brands in the UK and China. Journal of Brand Management, 14, 211-222.

Bikoff, J. L., Heasley, D. K., Sherman, V., \& Stipelman, J. (2015). Fake it 'till we make it: Regulating dangerous counterfeit goods. Journal of International Property Law \& Practice, 1O(4), 246254.

Cohen, M. (2000). Measuring the costs and benefits of crime and justice. In Duffee, D. (Ed.), Criminal justice: Measuring and analysis of crime and justice. Washington DC. NIJ, Vol. 4.

Choo, K. K. R., \& Smith, R. G. (2008). Criminal exploitation of online systems by organized crime groups. Canberra: Springer. Asian Criminology, 3, 37-59.

Clarke, R. V. (1997). Situational crime prevention: Successful case studies. $2^{\text {nd }}$ edition. New York: Harrow and Heston.

Cohen, L. E., \& Felson, M. (1979). Social change and crime rate trends: A routine activity approach. American Sociological Review, 44, 588-608.

Creswell, J. W. (2014). Research design: Qualitative, quantitative, and mixed methods approaches. $4^{\text {th }}$ edition. Los Angeles: Sage.

De Chermatony, L., Mcdonald, M., \& Wallace, E. (2011). Creating powerful brands. $4^{\text {th }}$ edition. Oxford: Butterworth-Heinemann.

Estacio, L. S. (2013). Showdown in Chinatown: Criminalizing the purchase of counterfeit goods. Setan Hall Legislative Journal, 37(3), 382-410.

Financial Action Task Team Guidance (2013). Money laundering and terrorist financing through trade in diamonds. Paris: Edmont group of financial intelligence units.

Forst, B. (2009). Terrorism, crime, and public policy. New York: Cambridge.

Gastrow, P. (1999). Main trends in the development of South Africa's organised crime. African Security Review, 5(6), 58-69.

Govender, D. (2012). Reflections on the strategic leadership in the South African Police Service on violent crimes and policing. Acta Criminologica: Southern African Journal of Criminology. CRIMSA 2011 Conference Special Edition, 2, 1-16.

Heike, S. (2010). Effects of counterfeits in the image of luxury brands: An empirical study from the consumer perspectives. Journal of Brand Management, 18(2), 159-173.

Heinonen, J. A., \& Wilson, J.M. (2012). Product counterfeit at the state level: An empirical examination of Michigan related incidents. International Journal of Comparative and Applied Criminal Justice, 36(4), 273-290.

ICC (2010). Intellectual property: Powerhouse for innovation and economic growth. New York: International Chamber of Commerce. 
INTERPOL (2014). Against organized crime: INTERPOL trafficking and counterfeiting casebook for 2014. Lyon: INTERPOL.

Joossens, L., Chaloupka, F., Merriman, D., \& Yurekli, A. (2000). Issues in the smuggling of tobacco products. New York: Oxford University Press.

Joyce, P. (2011). Policing: Development contemporary practice. London: Sage.

Kerns, R. W. (2016). The counterfeit food crisis in China: A systemic problem and possible solutions. North Carolina Journal of International Law \& Commercial Regulation, XLI, 573-593.

Klijn, E. H., Eshuis, J., \& Braun, E. (2012). The influence of stakeholder involvement on the effectiveness of place branding. Journal of Public Management Review, 14, 499-519.

Large, J. (2009). Consuming Counterfeits: exploring assumptions about fashion counterfeiting. British Society of Criminology, 9, 3-20.

Levy-Carciente, S. (2016). International Property Rights (2016). Retrieved 11 January 2020, from http://s3.amazonaws.com/ipri2016/IPRI+2016+Full+Report.pdf.

Le Khac, N. N., Markos, S., O’neill, M., Brabazon, A., \& Kechadi, T. (2011). An investigation into data mining approaches for anti-money laundering. IACSIT, 2, 504-508.

Lewis, K. (2009). The fake and the fatal: The consequences of counterfeits. London: The Park Place Economist.

Mackrell, N. (1996). Economics consequences of money laundering in the $21^{\text {st }}$ century: risks and countermeasures. Canberra: Australian Institute of Criminology.

Miles, M. B, Huberman, A. M., \& Saldana, J. (2014). Qualitative data analysis: A methods source book. $3^{\text {rd }}$ edition. London: Sage.

OECD (1998). The economic impact of counterfeit. Paris: OECD.

Payne, B. K. (2013). White-collar crime: The essentials. Washington DC: Sage.

Phau, I., \& Teah, M. (2009). Devil wears counterfeit Prada: A study of antecedents and outcomes of attitudes towards counterfeits of luxury brands. Journal of Consumer Marketing, 26(1), 15-27.

Pires, S. F., Schneider, J. L., \& Herrera, M. (2016). Organized crime or crime that is organized? The Parrot trade in the neotropics. Trends in Organized Crime, 19, 4-20.

Reynald, D. M. (2011). Guarding against crime: measuring guardianship within Routine Activity Theory. New York: Taylor Francis.

Rich, S. (2016). Corporate criminals and punishment theory. The Canadian Journal of Law \& Jurisprudence, $X X I X(1)$, 97-118.

Rojek, C. (2016). Counterfeit commerce: Relations of production, distribution and exchange. Cultural sociology, 1-16.

SAFACT (2009). Piracy in South Africa. Retrieved 29 December 2019, from http://safact.co.za/piracyfacts.

Siegel, L. J. (2010). Criminology: Theories, patterns and typologies. $10^{\text {th }}$ edition. Belmont: Wadsworth.

Sonmez, E. (2014). Cottage piracy, 3D printing and secondary trademark liability: Counterfeit luxury trademarks and DIY. Journal of San Francisco Law Review, 48, 757-792.

South African Institute of Intellectual Property Law (2013). Anti-counterfeiting. Pretoria: SAIIPL.

South African Police Services (2018). National Crime statistics for the South African Police Services 2017/18. Pretoria: Government Printers.

South Africa (1998). Prevention of Organised Crime Act 121 of 1998. Pretoria: Government Printer.

South Africa (1995). South African Police Service Act (SAPS Act) 68 of 1995. Pretoria: Government Printer. 
G. Thenga - An Evaluative Study of Criminalistics: A Case of South African Counterfeiting...

South Africa (1996). Constitution of the Republic of South Africa, Act No. 108 of 1996. Pretoria: Government Printer.

South Africa (1978). Copyright Act, 1978. (Act 98 of 1978). Pretoria: Government Printer.

South Africa (1997). Counterfeit goods Act, 1997. (Act 37 of 1997). Pretoria: Government Printer.

Spilsbury, R. (2009). Counterfeit: Stopping fakes and forgeries. Los Angeles: Enslow.

Spink, J., Meyer, D., Park, H., \& Heinonem, J. (2013). Defining the types of counterfeiters, counterfeiting, and offender organisations. Crime Science: An Interdisciplinary Journal, 2(1), 1-10.

Spoor \& Fisher (2013). The allure of Africa's rapidly growing economy to counterfeiters. Pretoria: Spoor \& Fisher.

Staake, T., \& Fleisch, E. (2008). Countering trade: Illicit market insights best-practice strategies and management toolbox. Heidelberg: Springer.

TRIPS (1995). Agreement on trade-related aspects of intellectual property rights. Geneva: World Trade Organization.

Treadwell, J. (2011). From the car boot to booting it up? Ebay, online counterfeit crime and transformation of the criminal market. Criminology and Criminal Justice, 12(2), 175-191.

Tuba, D. (2012). Prosecuting money laundering the FATF way: An analysis of gaps and challenges in South African legislation from a comparative perspective. Acta Criminologica: Southern African Journal of Criminology. CRIMSA 2011 Conference Special Edition, 2, 103-122.

UNICRI (2011). Counterfeiting: A global spread, a global threat. Turin: United Nations Interregional Crime and Justice Research Institute.

United Nations (2004). United Nations Convention Against Transnational Organized Crime and The Protocols Thereto. New York: United Nations.

Ward, M. (2011). A straight forward guide to intellectual property and the law. Brighton: Straightforward Publishers.

WIPO (2014). What is Intellectual Property? Retrieved 24 June 2019, from http.www.wipo.int/edocs/ pubdocs/en/intproperty/450/wipo -pub-450. pdf.

' The paper is previously published in Thenga, G. (2020). An evaluative study of criminalistics: A case of South African counterfeiting and knock-off menace. In T. V. Petkova \& V. S. Chukov (Eds.), 5th International e-Conference on Studies in Humanities and Social Sciences: Conference Proceedings (pp. 116). Belgrade: Center for Open Access in Science. https://doi.org/10.32591/coas.e-conf.05.01001t 